OPEN ACCESS

Edited by:

James Rohan,

University College Cork, Ireland

Reviewed by:

Maksudul Hasan,

Newcastle University, United Kingdom

Xinhui Xia,

Zhejiang University, China

*Correspondence:

Ziying Zhang

zzying@sues.edu.cn

Specialty section:

This article was submitted to

Electrochemistry,

a section of the journal

Frontiers in Chemistry

Received: 03 December 2019 Accepted: 21 February 2020

Published: 06 March 2020

Citation:

Xu P, Zhang Z, Zhang $H$, Shen $A$,

Zhao Y, Zhou Y and Weng Y (2020)

Binder-Free Charantia-Like

Metal-Oxide Core/Shell Nanotube

Arrays for High-Performance

Lithium-Ion Anodes.

Front. Chem. 8:159.

doi: 10.3389/fchem.2020.00159

\section{Binder-Free Charantia-Like Metal-Oxide Core/Shell Nanotube Arrays for High-Performance Lithium-Ion Anodes}

\author{
Pingping $X u^{1}$, Ziying Zhang ${ }^{1 *}$, Huizhen Zhang ${ }^{2}$, Ao Shen ${ }^{1}$, Yangqiang Zhao', \\ Yangyang Zhou ${ }^{1}$ and Ying Weng ${ }^{1}$ \\ ${ }^{1}$ School of Materials Engineering, Shanghai University of Engineering Science, Shanghai, China, ${ }^{2}$ School of Management, \\ University of Shanghai for Science and Technology, Shanghai, China
}

The performance of anodes of lithium-ion batteries relies largely on the architecture and composition of the hybrid active materials. We present a two-step, seed-free, solution-based method for the direct growth of hierarchical charantia-like $\mathrm{TiO}_{2} / \mathrm{Fe}_{2} \mathrm{O}_{3}$ core/shell nanotube arrays on carbon cloth substrates. An ultrahigh loading of the nanomaterial on carbon fibers was achieved with this method without the use of a binder. This three-dimensional porous hollow architecture and its direct contact with the $\mathrm{CC}$ current collector ensure an efficient electronic pathway. The hollow $\mathrm{TiO}_{2}$ framework effectively protects the hierarchical charantia-like $\mathrm{TiO}_{2} / \mathrm{Fe}_{2} \mathrm{O}_{3}$ hollow core/shell arrays from collapsing because of its negligible volume change during cycling. Meanwhile, the self-assembled $\alpha-\mathrm{Fe}_{2} \mathrm{O}_{3}$ hollow nanospheres guarantee a large capacity and contact area with the electrolyte. This flexible anode with a 3D porous charantia-like hollow architecture exhibits high cycle performance, reversible capacity, and rate capability. These nanotube arrays maintain a high reversible capacity of $875 \mathrm{mAh} \mathrm{g}^{-1}$ after 200 cycles at a current density of $200 \mathrm{~mA} \mathrm{~g}^{-1}$. This simple, cost-effective, and scalable electrode fabrication strategy can be implemented in the fabrication of high-performance wearable energy storage devices.

Keywords: carbon fabric, $\mathrm{TiO}_{2}$ nanotube arrays, $\alpha-\mathrm{Fe}_{2} \mathrm{O}_{3}$ hollow nanospheres, lithium-ion batteries, anodes

\section{INTRODUCTION}

Lithium-ion batteries (LIBs) are popular energy storage devices because of their high energy density, high open-circuit voltage, lack of memory effects, and shape controllability (Joshi et al., 2016; Zhao et al., 2016; Shen et al., 2018; Deng et al., 2019). The design of electrode materials with high energy density and cycling stability is important for enhancing the performance of LIBs. Graphite - the most widely used commercial anode material — cannot fulfill the increasing demands with regard to the energy density and stability of an electrode owing to its low theoretical capacity $\left(372 \mathrm{mAh} \mathrm{g}^{-1}\right)$, poor rate performance, and intrinsic stability. Therefore, much attention has been focused on exploring anode materials with higher capacity for next-generation LIBs (Liu et al., 2019; Partheeban and Sasidharan, 2019; Shen et al., 2019).

$\mathrm{TiO}_{2}$ is a promising anode candidate owing to its relatively good conductivity, low cost, higher operation voltage, and low volume expansion. However, its practical application is impeded by its 
low theoretical capacity. Owing to its unique physical and chemical properties as a nanomaterial, $\mathrm{TiO}_{2}$ is engineered into various nanostructures with different morphologies to improve the specific capacity (Moretti et al., 2013; Ying et al., 2017; Smith et al., 2019). Despite immense progress in this area, the effect of scaling down on the performance of $\mathrm{TiO}_{2}$ has been limited due to its theoretical capacity limitation. Recent studies have indicated that $\mathrm{TiO}_{2}$-based nanocomposites obtained by combining them with high-capacity metal oxides could facilitate high performance at a smaller scale (Zhu et al., 2014; Wang et al., 2015; Lee et al., 2017; Yang et al., 2018; Zhang et al., 2019). Hematite $\left(\alpha-\mathrm{Fe}_{2} \mathrm{O}_{3}\right)$ is a promising mineral for preparing a hybrid with $\mathrm{TiO}_{2}$ because of its relatively higher theoretical capacity $\left(\sim 1,000 \mathrm{~mA} \mathrm{~h} \mathrm{~g}^{-1}\right)$, non-toxicity, high corrosion resistance, and abundant resource (Gao et al., 2014; Li et al., 2016; Jiang et al., 2017; Zhao et al., 2019). When $\mathrm{Fe}_{2} \mathrm{O}_{3}$ is anchored onto the surface of a $\mathrm{TiO}_{2}$ nano-backbone, its high theoretical capacity compensates for the deficient capacity of the $\mathrm{TiO}_{2}$ nano-backbone, while the good conductivity and low volume expansion of $\mathrm{TiO}_{2}$ ensures excellent cyclic stability of the hybrid material (Luo et al., 2012; Yang et al., 2017). One-dimensional (1D) nanotube arrays and threedimensional (3D) hollow spheres can promote rate capability by offering an efficient electronic pathway (Han et al., 2011; Wang et al., 2012; He et al., 2018). Therefore, we fabricated $3 \mathrm{D}$ nanotube arrays by coating $\mathrm{Fe}_{2} \mathrm{O}_{3}$ hollow nanospheres on $\mathrm{TiO}_{2}$ nanotube arrays to realize high-performance rechargeable batteries. However, the direct growth of a 3D porous hollow composite architecture on a flexible substrate without a binder remains a major challenge.

In this study, 3D hierarchical charantia-like $\mathrm{TiO}_{2} / \mathrm{Fe}_{2} \mathrm{O}_{3}$ nanotube arrays were grown directly on a carbon cloth (CC) substrate by a facile hydrothermal method. The $\mathrm{CC} / \mathrm{TiO}_{2}$ nanotube arrays decreased the fracture risk caused by the volume fluctuation during lithium-ion insertion and extraction, while the $\alpha-\mathrm{Fe}_{2} \mathrm{O}_{3}$ nanosphere shell assembled on the surface of $\mathrm{TiO}_{2}$ nanotube increased the surface area and number of active sites. Direct contact of the active material with the CC substrate and the hollow structure facilitated an efficient electronic pathway. Their unique hollow core-shell structure endowed the final electrodes with high energy, reversible capacity, and cycle performance.

\section{EXPERIMENTAL METHOD}

\section{Synthesis of $\mathrm{TiO}_{2}$ Nanotube Arrays on CC}

Before the experiment, the $\mathrm{CC}$ substrates were immersed in nitric acid at $30^{\circ} \mathrm{C}$ for $3 \mathrm{~h}$, and then ultrasonically cleaned with distilled water and ethanol for $30 \mathrm{~min}$. $\mathrm{TiO}_{2}$ nanotube arrays were synthesized by a facile hydrothermal method. Analytically pure reagents were used without further purification. Typically, $1 \mathrm{~mL}$ of tetrabutyl titanate, $12 \mathrm{~mL}$ of glycerinum, and $45 \mathrm{~mL}$ of ethanol were magnetically stirred at room temperature to form a homogeneous precursor solution. The precursor was then poured into a $100 \mathrm{~mL}$ Teflon-lined autoclave with a piece of clean CC $(7 \times 5.0 \mathrm{~cm})$ and maintained at $175^{\circ} \mathrm{C}$ for $20 \mathrm{~h}$. After the reaction, the white byproduct on the $\mathrm{CC}$ was washed with ethanol and distilled water, and $\mathrm{CC} / \mathrm{TiO}_{2}$ nanotube arrays were obtained after heating the products at $350^{\circ} \mathrm{C}$ for $1 \mathrm{~h}$.

\section{Growth of $\mathrm{Fe}_{2} \mathrm{O}_{3}$ Nanospheres on $\mathrm{CC} / \mathrm{TiO}_{2}$ Nanotube Arrays}

The as-prepared $\mathrm{CC} / \mathrm{TiO}_{2}$ nanotube arrays were used as scaffolds for growing $\alpha-\mathrm{Fe}_{2} \mathrm{O}_{3}$ hollow nanospheres via a simple hydrothermal method. $\mathrm{FeCl}_{3} \cdot 6 \mathrm{H}_{2} \mathrm{O}(1.688 \mathrm{~g}$ ) and ammonia $(0.1 \mathrm{~mL})$ were dissolved in $40 \mathrm{~mL}$ of deionized water in a $100 \mathrm{~mL}$ Pyrex beaker and stirred to form a clear tan solution. The final mixture was transferred to an $80 \mathrm{~mL}$ Teflon-lined autoclave and heated at $95^{\circ} \mathrm{C}$ for $4 \mathrm{~h}$. The products were washed several times with ethanol and water. The dried products were further annealed in a $\mathrm{N}_{2}$ atmosphere at $450^{\circ} \mathrm{C}$ for $2 \mathrm{~h}$.

\section{Characterization of the Structure and Morphology}

Phase purity of the synthesized products was examined by Xray powder diffraction (XRD, Panalytical X'Pert, Netherlands) carried out with $\mathrm{Cu}-K \alpha$ radiation $(\lambda=1.5418 \AA)$. The morphology of the products was characterized by field-emission scanning electron microscopy (SEM, Model: JEOL JSM-7000F, Japan) and high-resolution transmission electron microscopy (HRTEM, Model: FEI Titan X 60-300, USA). FA1004 electronic balance was used to measure the weight difference between the prepared electrode and CC substrate, and the mass loading of the active material was obtained. X-ray photoelectron spectroscopy (XPS) was performed on a Perkin-Elmer model PHI 5600 XPS system, with a monochromated aluminum anode as the X-ray source. The specific surface area of the obtained products was calculated by the Brunauer-Emmett-Teller (BET) method using the nitrogen adsorption-desorption isotherm acquired from a Micrometics Tristar 3000 system.

\section{Electrochemical Measurements}

Electrochemical tests were performed in CR 2032 coin halfcells assembled in an argon-filled glovebox using the as-prepared hierarchical nanotube arrays as the anode and circular lithiummetal foil as the cathode. A solution of $1 \mathrm{M} \mathrm{LiPF}_{6}$ in ethylene carbonate and diethyl carbonate at a volume ratio of 1:1 was used as the electrolyte. The cells were galvanostatically charged and discharged using a multichannel battery tester (NewareCT3008). With lithium-metal foil as the counter and reference electrodes, Cyclic voltammetry (CV) of the coin half-cells was performed on a PARSTAT 4000 electrochemical workstation at a scan rate of $0.2 \mathrm{mV} \mathrm{s}^{-1}$ in the range of $3.0-0.01 \mathrm{~V}$ vs. $\mathrm{Li} / \mathrm{Li}^{+}$. Electrochemical impedance spectroscopy (EIS) was performed in a wide frequency range of $100 \mathrm{kHz}$ to $0.01 \mathrm{~Hz}$ at an $\mathrm{AC}$ perturbation voltage of $5 \mathrm{mV}$.

\section{RESULTS AND DISCUSSION}

\section{Synthesis and Characterization}

Scheme 1 shows the synthesis of the 3D hierarchical charantialike $\mathrm{CC} / \mathrm{TiO}_{2} / \mathrm{Fe}_{2} \mathrm{O}_{3}$ nanotube arrays. First, the $\mathrm{TiO}_{2}$ nanotube arrays were fabricated on a CC substrate by a facile seedfree hydrothermal method. After annealing the obtained product in air at $350^{\circ} \mathrm{C}$ for $1 \mathrm{~h}$, the amorphous $\mathrm{TiO}_{2}$ cores crystallized into one-dimensional (1D) $\mathrm{CC} / \mathrm{TiO}_{2}$ nanotube arrays. Subsequently, ultrathin $\mathrm{FeOOH}$ nanosheets were 


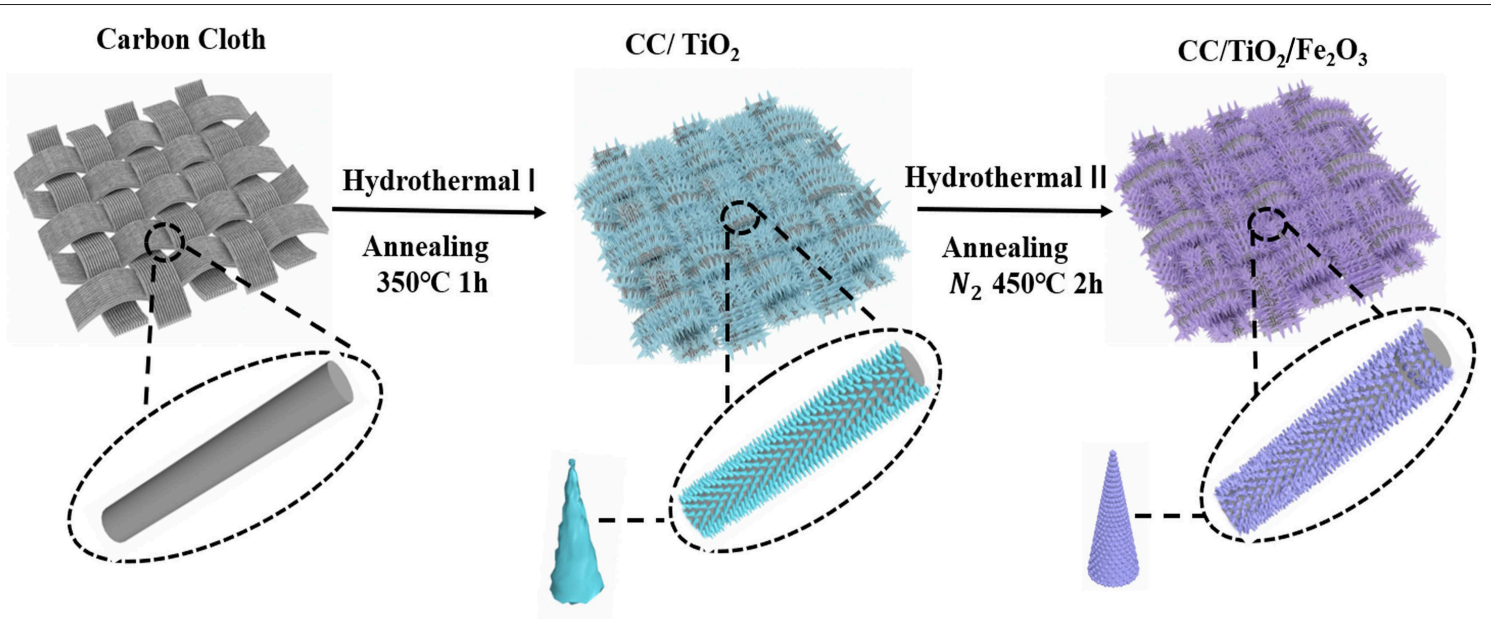

SCHEME 1 | Schematic illustration of the synthesized procedures of $\mathrm{CC} / \mathrm{TiO}_{2} / \mathrm{Fe}_{2} \mathrm{O}_{3}$ hollow nano-arrays.
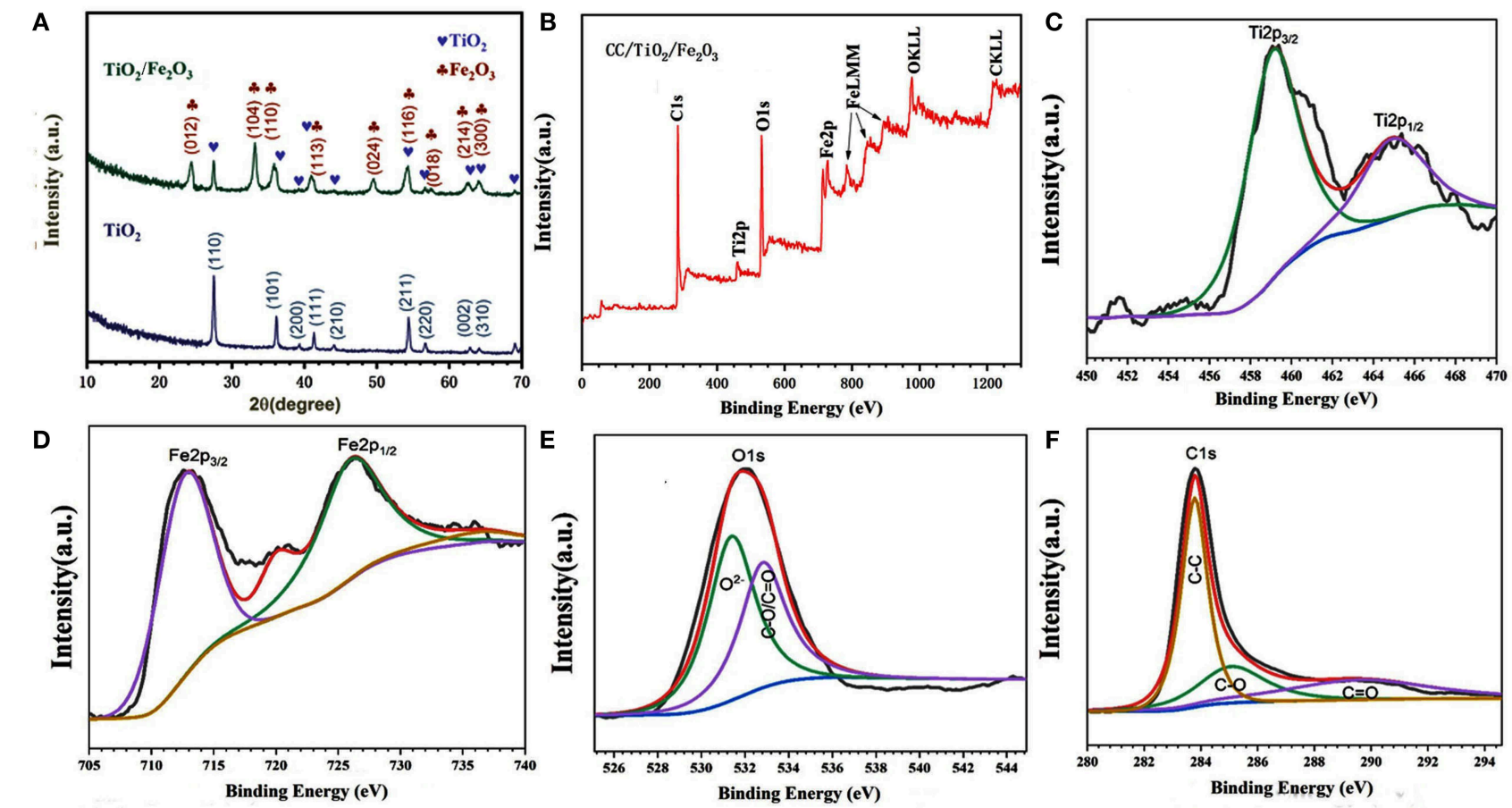

FIGURE 1 | (A) XRD pattern of $\mathrm{CC} / \mathrm{TiO}_{2}$ and $\mathrm{CC} / \mathrm{TiO}_{2} / \mathrm{Fe}_{2} \mathrm{O}_{3}$ hollow nano-arrays. XPS spectra of $\mathrm{CC} / \mathrm{TiO}_{2} / \mathrm{Fe}_{2} \mathrm{O}_{3}$ specimens. (B) Survey spectra. (C) Ti2p core-level spectra, (D) Fe2p core-level spectra. (E) O1s core-level spectra, and (F) C1s core-level spectra.

grown on the surface of the $\mathrm{CC} / \mathrm{TiO}_{2}$ nanotube arrays and then spontaneously transformed into hollow nanospheres by the forced hydrolysis of $\mathrm{FeCl}_{3}$, without the use of any structure-directing agent. $\mathrm{FeOOH}$ hollow nanospheres grown on the $\mathrm{CC} / \mathrm{TiO}_{2}$ nanotube arrays were further transformed into $\alpha-\mathrm{Fe}_{2} \mathrm{O}_{3}$ hollow nanospheres through thermal dehydroxylation and lattice shrinkage at a high temperature, leading to the formation of the charantia-like $\mathrm{CC} / \mathrm{TiO}_{2} / \mathrm{Fe}_{2} \mathrm{O}_{3}$ nanotube arrays.
XRD measurements were performed to confirm the crystalline structure of the obtained products. Figure 1A shows the corresponding XRD patterns of $\mathrm{TiO}_{2}$ and $\mathrm{TiO}_{2} / \mathrm{Fe}_{2} \mathrm{O}_{3}$ products scratched from CC substrates. All the diffraction peaks of the $\mathrm{TiO}_{2}$ products matched well with those of typical tetragonal rutile $\mathrm{TiO}_{2}$ (JCPDS No. 21-1272). The lattice parameters of the obtained tetragonal rutile $\mathrm{TiO}_{2}$ nanotube are $\mathrm{a}=\mathrm{b}=4.516$ $\AA$ and $c=5.205 \AA$. These are consistent with those reported by Luo et al. (2012). Three additional peaks were observed in 

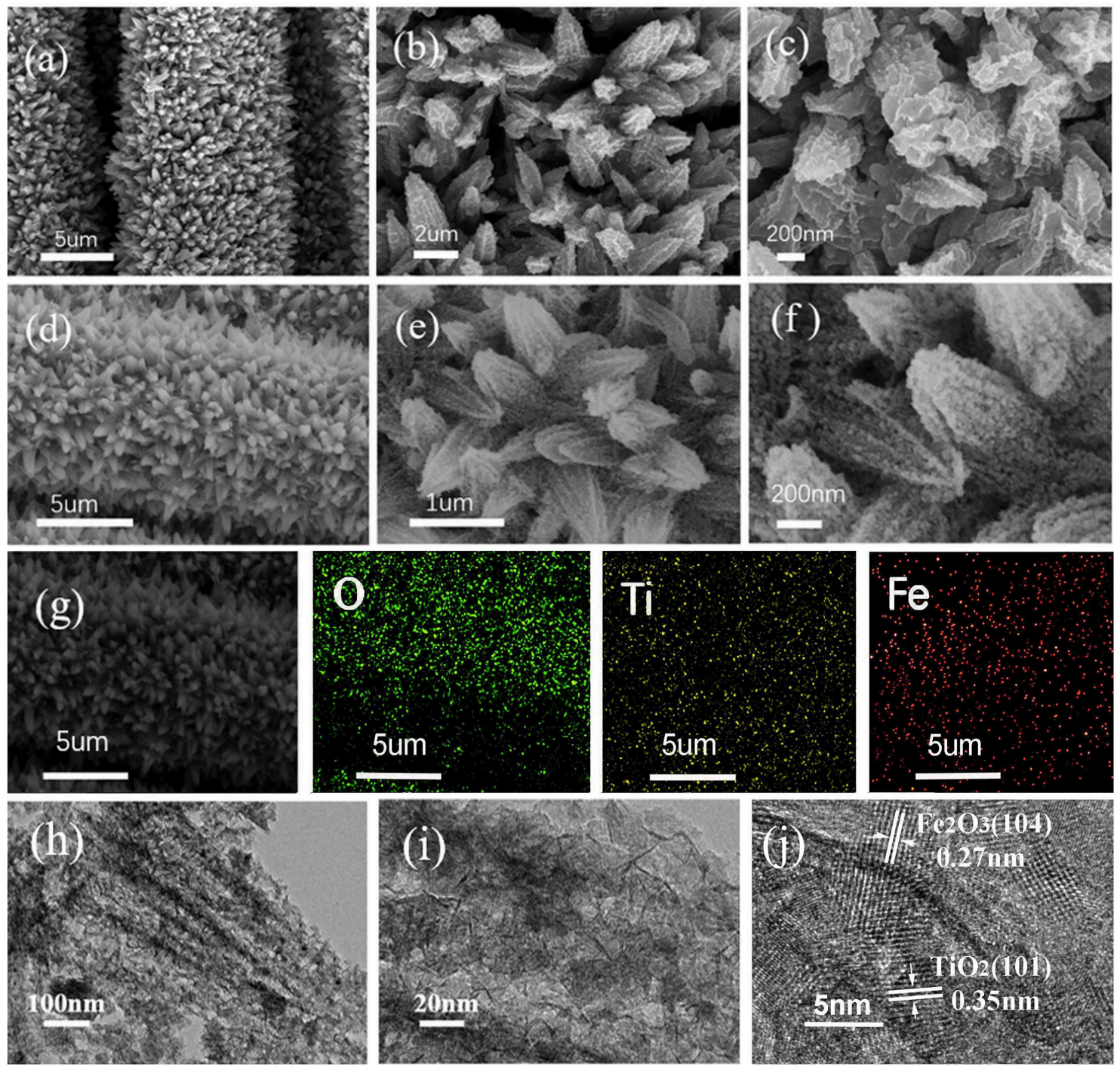

FIGURE 2 | SEM images of the prepared specimens at different magnifications. (a-c) $\mathrm{CC} / \mathrm{TiO} \mathrm{i}_{2}$ specimens. (d-f) $\mathrm{CC} / \mathrm{TiO}_{2} / \mathrm{Fe}_{2} \mathrm{O}_{3}$ specimens. (g) EDX elemental mapping of the $\mathrm{CC} / \mathrm{TiO}_{2} / \mathrm{Fe}_{2} \mathrm{O}_{3}$ specimens. (h-j) TEM and HRTEM images of $\mathrm{CC} / \mathrm{TiO}_{2} / \mathrm{Fe}_{2} \mathrm{O}_{3}$ specimens.

the XRD pattern of the $\mathrm{TiO}_{2} / \mathrm{Fe}_{2} \mathrm{O}_{3}$ composite. These peaks located at $33.1,35.6$, and $54.1^{\circ}$ correspond to the (104), (110), and (116) planes of $\alpha-\mathrm{Fe}_{2} \mathrm{O}_{3}$ (JCPDS No. 33-0664), respectively, indicating the successful preparation of an $\alpha-\mathrm{Fe}_{2} \mathrm{O}_{3}$ shell on the $\mathrm{TiO}_{2}$ nanotube core (Larcher et al., 2003; Qi et al., 2018).

XPS was performed to identify the chemical states and surface composition of the final composite. The spectra are shown in Figures 1B-F. Only the peaks of $\mathrm{Ti}, \mathrm{O}, \mathrm{Fe}$, and $\mathrm{C}$ are found in the survey spectrum of the $\mathrm{CC} / \mathrm{TiO}_{2} / \mathrm{Fe}_{2} \mathrm{O}_{3}$ composite. The XPS spectrum of the $\mathrm{C}$ 1s core-level could be divided into three peaks (Figure 1C). The peak at $283.7 \mathrm{eV}$ indicates the non-oxygenated carbon. The other two peaks at 284.9 and $289.1 \mathrm{eV}$ correspond to the carbon ramifications generated in the hydrothermal reaction and annealing process. The deconvoluted peaks of the $\mathrm{O} 1 \mathrm{~s}$ spectrum could also be decomposed into two components centered at 531.3 and $533.8 \mathrm{eV}$, respectively. The low binding energy component is attributed to the $\mathrm{O}_{2}^{-}$attached to $\mathrm{Ti}$ and $\mathrm{Fe}$, the other component corresponds to the oxygen in $\mathrm{C}-\mathrm{O}$ and $\mathrm{O}-\mathrm{C}=\mathrm{O}$ bonds. The Ti $2 \mathrm{p}$ XPS spectrum exhibits bimodal characteristics. The peaks located at 460 and $466 \mathrm{eV}$ correspond to Ti $2 p_{3 / 2}$ and Ti $2 p_{1 / 2}$, respectively (Wang et al., 2016). The binding energy difference of $5.8 \mathrm{eV}$ between the Ti $2 \mathrm{p}_{1 / 2}$ and $\mathrm{Ti}$ $2 p_{3 / 2}$ core levels indicated that the oxidation state of $\mathrm{Ti}$ is mainly $\mathrm{Ti}(4+)$. Similarly, the typical bimodal characteristics of the $\mathrm{Fe}$ $2 p$ XPS spectrum also confirmed the existence of surface $\mathrm{Fe}$ as a trivalent oxide (Luo et al., 2012; Yang et al., 2017). Consistent with the results of XRD, the XPS analysis revealed that the obtained composites are composed of $\alpha-\mathrm{Fe}_{2} \mathrm{O}_{3}$ and $\mathrm{TiO}_{2}$.

The morphology and microstructure of the as-obtained composite were characterized by SEM and TEM. Figures 2a-c 

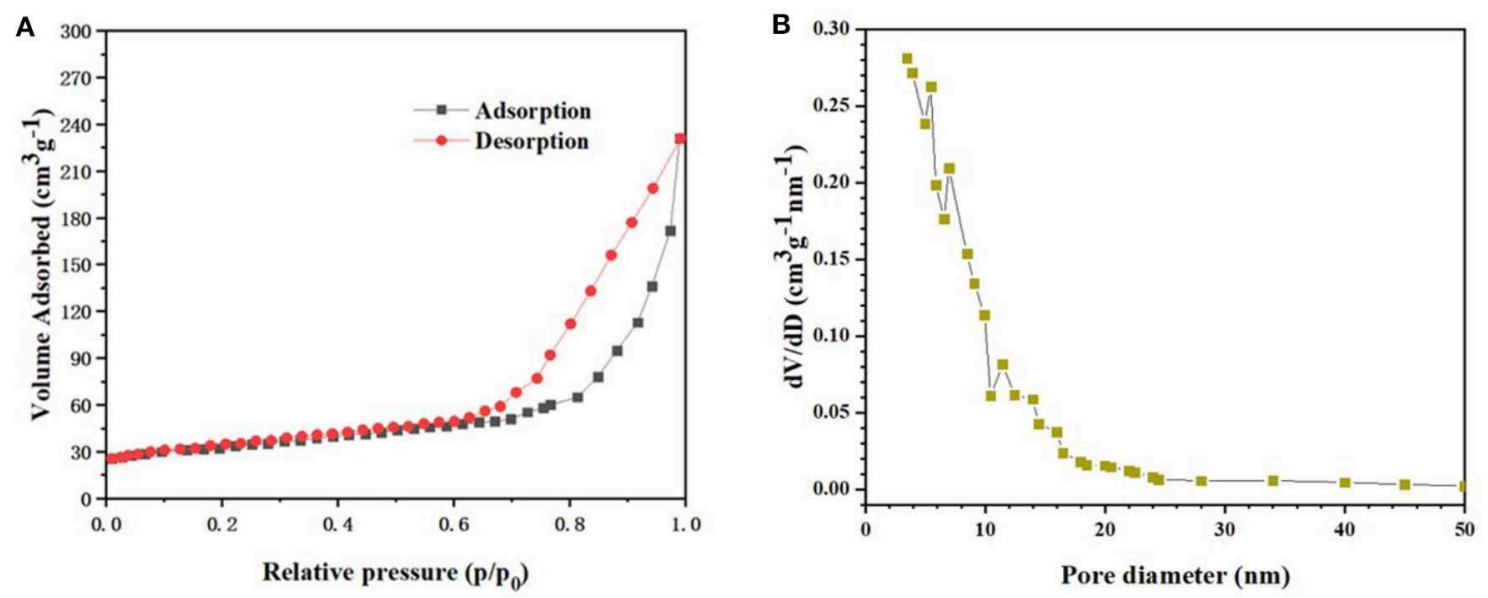

FIGURE 3 | (A) The $\mathrm{N}_{2}$ adsorption/desorption isotherms and (B) pore size distribution of $\mathrm{CC} / \mathrm{TiO}_{2} / \mathrm{Fe}_{2} \mathrm{O}_{3}$ hollow nano-arrays.
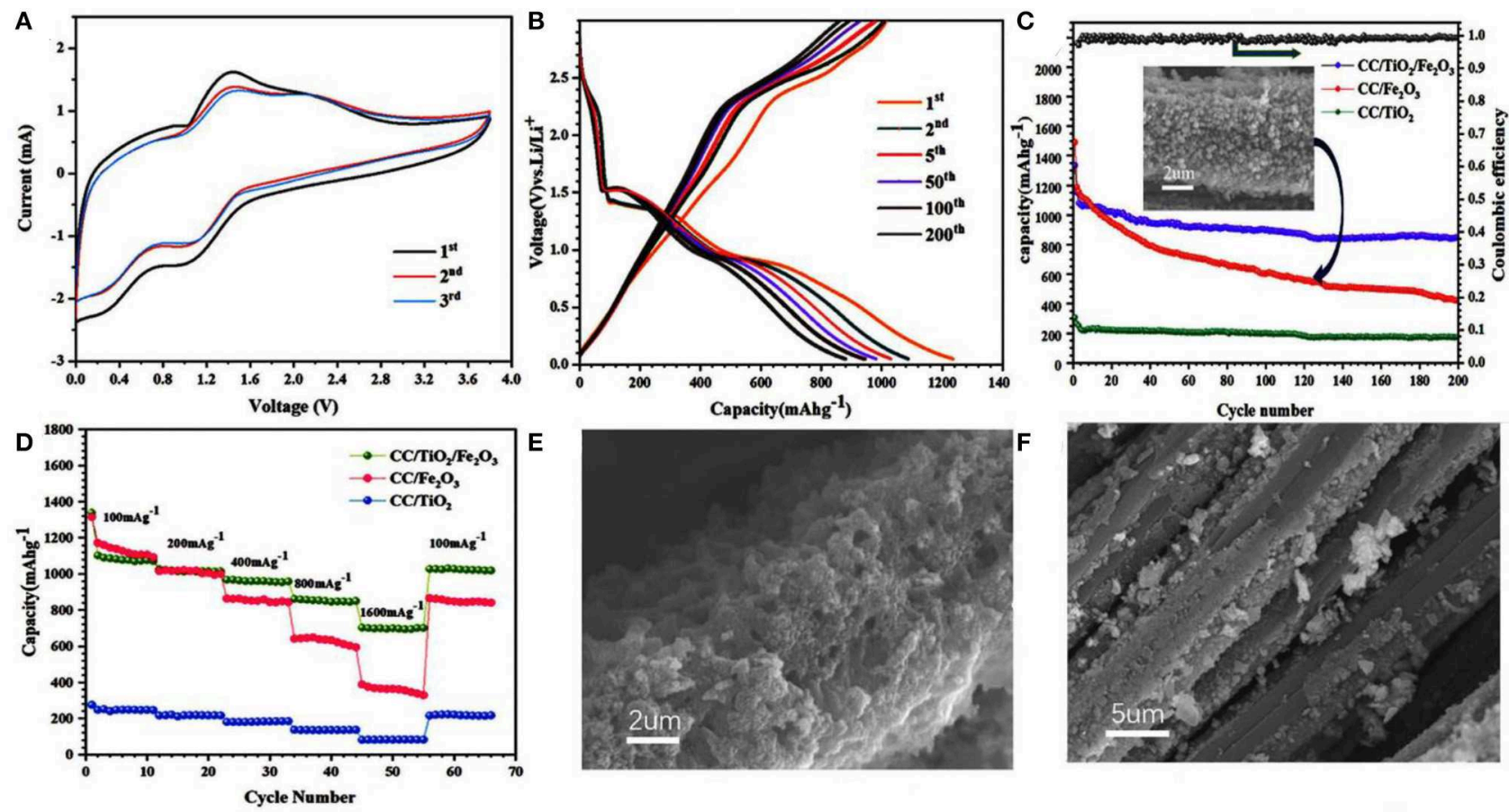

FIGURE 4 | (A) CV curves of $\mathrm{CC} / \mathrm{TiO}_{2} / \mathrm{Fe}_{2} \mathrm{O}_{3}$ specimens between $5 \mathrm{mV}$ and $3.8 \mathrm{~V}$ at a scan rate of $0.5 \mathrm{mVs}^{-1}$. (B) $\mathrm{Charge-discharge} \mathrm{voltage} \mathrm{profiles} \mathrm{of}$ $\mathrm{CC} / \mathrm{TiO}_{2} / \mathrm{Fe}_{2} \mathrm{O}_{3}$ specimens at a constant current rate of $200 \mathrm{mAg}^{-1}$. (C) Cycling performances of $\mathrm{CC} / \mathrm{TiO}_{2} / \mathrm{Fe}_{2} \mathrm{O}_{3}, \mathrm{CC} / \mathrm{TiO}$, and $\mathrm{CC} / \mathrm{Fe} \mathrm{O}_{3} \mathrm{O}_{3} \mathrm{specimens}$ at a constant current rate of $200 \mathrm{~mA} \mathrm{~g}^{-1}$. (D) Rate performances of $\mathrm{CC} / \mathrm{TiO}_{2} / \mathrm{Fe}_{2} \mathrm{O}_{3}, \mathrm{CC} / \mathrm{TiO}_{2}$, and $\mathrm{CC} / \mathrm{Fe}_{2} \mathrm{O}_{3}$ specimens. SEM image of (E) CC/TiO $/ \mathrm{Fe}_{2} \mathrm{O}_{3}$ and (F) $\mathrm{CC} / \mathrm{Fe}_{2} \mathrm{O}_{3}$ specimens after 200 cycles.

show the SEM images of pure $\mathrm{CC} / \mathrm{TiO}_{2}$ nanotube arrays at different magnifications. It is obvious that the $1 \mathrm{D} \mathrm{TiO}_{2}$ nanotube arrays grew uniformly and vertically on the CC substrate in a carambola-like configuration. The high-magnification SEM images clearly show that the $1 \mathrm{D}$ carambola-like $\mathrm{TiO}_{2}$ nanotube arrays have a mean bottom diameter of $500 \mathrm{~nm}$. Their walls were assembled from several small nanosheets, leading to the roughening of the surface of the $\mathrm{TiO}_{2}$ nanotube arrays. A rough surface facilitates the heterogeneous nucleation of $\mathrm{Fe}_{2} \mathrm{O}_{3}$ nanoparticles. Figures 2d-f present the SEM images of $\mathrm{CC} / \mathrm{TiO}_{2} / \mathrm{Fe}_{2} \mathrm{O}_{3}$ nanocomposite arrays at different magnifications. As seen, a large number of nanospheres adhered to the surface of the carambola-like $\mathrm{TiO}_{2}$ nanotube arrays, forming a 3D hierarchical charantia-like structure. This association rendered the final nanotube arrays more compact and spatially dense, thus guaranteeing a high mass loading and 
TABLE 1 | List of research reports on $\mathrm{TiO}_{2} / \mathrm{Fe}_{2} \mathrm{O}_{3}$ as lithium-ion anodes.

\begin{tabular}{|c|c|c|c|}
\hline Materials & $\begin{array}{l}\text { Capacity/constant } \\
\text { current density }\end{array}$ & Cycles & References \\
\hline $\begin{array}{l}\mathrm{CC} / \mathrm{TiO}_{2} / \mathrm{Fe}_{2} \mathrm{O}_{3} \\
\text { nanotube arrays }\end{array}$ & $\begin{array}{l}896 \mathrm{mAh} \mathrm{g}^{-1} \\
200 \mathrm{~mA} \mathrm{~g}^{-1}\end{array}$ & 200 cycles & This work \\
\hline $\begin{array}{l}\mathrm{TiO}_{2} @ \mathrm{a}-\mathrm{Fe}_{2} \mathrm{O}_{3} \text { on } \\
\text { carbon textiles }\end{array}$ & $\begin{array}{l}480 \mathrm{mAh} \mathrm{g}^{-1} \\
120 \mathrm{~mA} \mathrm{~g}^{-1}\end{array}$ & 150 cycles & Luo et al., 2012 \\
\hline $\begin{array}{l}\mathrm{TiO}_{2} @ \alpha-\mathrm{Fe}_{2} \mathrm{O}_{3} \\
\text { carbon coated }\end{array}$ & $\begin{array}{l}516 \mathrm{mAh} \mathrm{g}^{-1} \\
200 \mathrm{~mA} \mathrm{~g}^{-1}\end{array}$ & 200 cycles & Luo et al., 2013 \\
\hline $\mathrm{TiO}_{2}-\mathrm{B} @ \alpha-\mathrm{Fe}_{2} \mathrm{O}_{3}$ & $\begin{array}{l}785 \mathrm{mAh} \mathrm{g}^{-1} \\
100 \mathrm{~mA} \mathrm{~g}^{-1}\end{array}$ & 100 cycles & Xia et al., 2014 \\
\hline $\mathrm{TiO}_{2} @ \alpha-\mathrm{Fe}_{2} \mathrm{O}_{3}$ & $\begin{array}{l}600 \mathrm{mAh} \mathrm{g}^{-1} \\
200 \mathrm{~mA} \mathrm{~g}^{-1}\end{array}$ & 200 cycles & Luo et al., 2013 \\
\hline
\end{tabular}

high specific capacity. The mass loading of $\mathrm{CC} / \mathrm{TiO}_{2} / \mathrm{Fe}_{2} \mathrm{O}_{3}$ nanocomposite arrays was $\sim 11.6 \mathrm{mg} \mathrm{cm}-^{2}$, higher than that of the pure $\mathrm{TiO}_{2} / \mathrm{CC}$ nano-arrays $\left(\sim 5.1 \mathrm{mg} \mathrm{cm}^{-2}\right)$. Owing to these features, the final nanotube arrays can remain ordered without undergoing any apparent structural collapse or breakage. Compared with the bare $\mathrm{TiO}_{2}$ nanotube arrays, the bottom diameters of the $3 \mathrm{D}$ hierarchical $\mathrm{CC} / \mathrm{TiO}_{2} / \mathrm{Fe}_{2} \mathrm{O}_{3}$ nano-composite arrays range up to $700 \mathrm{~nm}$, with negligible variation in the length. The surface of the charantia-like $\mathrm{CC} / \mathrm{TiO}_{2} / \mathrm{Fe}_{2} \mathrm{O}_{3}$ nanotube arrays is rougher and looser than that of the $1 \mathrm{D}$ bare $\mathrm{CC} /$ carambola-like $\mathrm{TiO}_{2}$ nanotube arrays. These characteristics improved the effective contact area with the electrolyte. Furthermore, the robust bottom of the charantialike nano-composite arrays increased their mechanical strength, thus reducing the fracture risk triggered by volume variations during lithiation/delithiation. This unique structure may lead to a large specific capacity and high cycling stability of the final product (Joshi et al., 2016; Zhang et al., 2019). Figure 2g displays the EDX mapping analysis of the charantia-like $\mathrm{CC} / \mathrm{TiO}_{2} / \mathrm{Fe}_{2} \mathrm{O}_{3}$ nanotube arrays. $\mathrm{Fe}, \mathrm{Ti}$, and $\mathrm{O}$ are evenly distributed on the surface of carbon fibers, further implying that the nanospheres coated on the surface of $1 \mathrm{D} \mathrm{TiO}_{2}$ nanotube arrays are iron oxides.

To investigate the microstructure of the charantia-like nanotube arrays, further TEM observations were made. Figures $\mathbf{2 h}-\mathbf{j}$ show the TEM images of the nanotube arrays scraped off the CC substrate. Figure $\mathbf{2 h}$ shows that both the $\mathrm{TiO}_{2}$ cores and $\mathrm{Fe}_{2} \mathrm{O}_{3}$ nanospheres have hollow interiors. The hollow $\mathrm{Fe}_{2} \mathrm{O}_{3}$ nanospheres are loosely assembled from numerous small nanosheets, indicating that they might have a mesoporous structure. Further, the HRTEM image shows that the lattice spacings of the $3 \mathrm{D}$ hierarchical charantialike $\mathrm{CC} / \mathrm{TiO}_{2} / \mathrm{Fe}_{2} \mathrm{O}_{3}$ nanotube arrays are 0.35 and $0.27 \mathrm{~nm}$, corresponding to the (101) plane of tetragonal rutile $\mathrm{TiO}_{2}$ and the (110) plane of $\alpha-\mathrm{Fe}_{2} \mathrm{O}_{3}$, respectively (Luo et al., 2012; Qi et al., 2018). This result further confirms that the nanotube arrays were composed of tetragonal rutile $\mathrm{TiO}_{2}$ and $\alpha-\mathrm{Fe}_{2} \mathrm{O}_{3}$.

BET gas-sorption measurements were performed to further investigate the porous nature and the specific surface area of the nanotube arrays. Figure $\mathbf{3 A}$ presents the nitrogen adsorption-desorption isotherm of the nanotube arrays. The typical IV isotherm with a distinct hysteresis loop in the range of $0.7-1.0 \mathrm{P} / \mathrm{Po}$ indicates that the charantia-like $\mathrm{TiO}_{2} / \mathrm{Fe}_{2} \mathrm{O}_{3}$ nanotube arrays have a mesoporous structure (Luo et al., 2013; Zhang et al., 2019). The BET specific surface area of the nanotube arrays was calculated to be $149.3 \mathrm{~m}^{2} \mathrm{~g}^{-1}$. The large specific surface area is mainly due to the extremely uneven charantia-like surface resulting from the well-wrapped $\mathrm{Fe}_{2} \mathrm{O}_{3}$ hollow nanospheres. The pore size distribution (Figure 3B) demonstrates that the main pore size of the nanotube arrays is approximately $13.4 \mathrm{~nm}$. According to the literature (Luo et al., 2012; Wang et al., 2016; Zhang et al., 2019), such a mesoporous structure can offer enough interface for lithium-ion insertion and extraction.

\section{Electrochemical Properties}

The electrochemical properties of the 3D hierarchical charantialike $\mathrm{CC} / \mathrm{TiO}_{2} / \mathrm{Fe}_{2} \mathrm{O}_{3}$ nanotube arrays were evaluated to further confirm the performance of the prepared nanotube arrays. Figure $4 \mathrm{~A}$ shows the first three $\mathrm{CV}$ cycles of a single redox couple in the voltage window of $0-3.8 \mathrm{~V}$ at a scanning rate of $0.5 \mathrm{mV} / \mathrm{s}$. The first CV curve shows two broad cathodic peaks at 1.05 and $0.42 \mathrm{~V}$, which mainly correspond to the generation of $\mathrm{Li}_{2} \mathrm{O}$ as well as the formation of a solid-electrolyte interface (SEI) (Luo et al., 2012; Yang et al., 2017). In the anodic process, the peak at $1.4 \mathrm{~V}$ indicates the oxidation of zero-valent iron to ferric iron, while the weak peak at $2.3 \mathrm{~V}$ is ascribed to the delithiation of $\mathrm{TiO}_{2}$. Except for the slight variation in the two cathodic peaks, the subsequent curves exhibit good reproducibility. The slight shift in the two cathodic peaks to higher potential reveal the occurrence of some irreversible processes during the first cycle. This result is consistent with the previous findings reported in literature (Luo et al., 2012; Qi et al., 2018; Zhang et al., 2019).

Figure 4B shows different cycle charge-discharge voltage profiles of the 3D hierarchical charantia-like $\mathrm{CC} / \mathrm{TiO}_{2} / \mathrm{Fe}_{2} \mathrm{O}_{3}$ nanotube arrays at a constant current density of $200 \mathrm{~mA} \mathrm{~g}^{-1}$. The plateau voltages in the first discharge curve are in good agreement with the oxidation peaks in the $\mathrm{CV}$ curves. The initial discharge and charge capacities are $\sim 1,280$ and 1,089 $\mathrm{mAh}$ $\mathrm{g}^{-1}$, respectively, corresponding to a low irreversible capacity loss $(\sim 15 \%)$. Figure $4 \mathrm{C}$ shows the cycling performances of the $\mathrm{CC} / \mathrm{TiO}_{2} / \mathrm{Fe}_{2} \mathrm{O}_{3}$ nanotube arrays as along with those of $\mathrm{CC} / \mathrm{TiO}_{2}$ nanotube arrays and $\mathrm{CC} / \mathrm{Fe}_{2} \mathrm{O}_{3}$ composites. The $\mathrm{CC} / \mathrm{Fe}_{2} \mathrm{O}_{3}$ composites were synthesized from clean $\mathrm{CC}$ using the same Fe ion hydrothermal system mentioned in the experimental section. Although the bare $\mathrm{CC} / \mathrm{TiO}_{2}$ nanotube arrays presented a perfect cycle performance, they had a low capacity. On the contrary, despite having a high capacity in the initial stage, the $\mathrm{CC} / \mathrm{Fe}_{2} \mathrm{O}_{3}$ composite showed a rapid decay of the capacity with cycling. The apparent decline in the capacity is mainly due to the drastic volume changes of $\mathrm{Fe}_{2} \mathrm{O}_{3}$ itself during lithiation, which led to the removal of the active material from the CC substrate. By contrast, the combination of low volume expansion of the $\mathrm{TiO}_{2}$ hollow cores and the strong adhesion between the two types of metallic oxides rendered the structure of the 3D nanotube arrays stable during lithiumion insertion/extraction processes. This feature further led to 

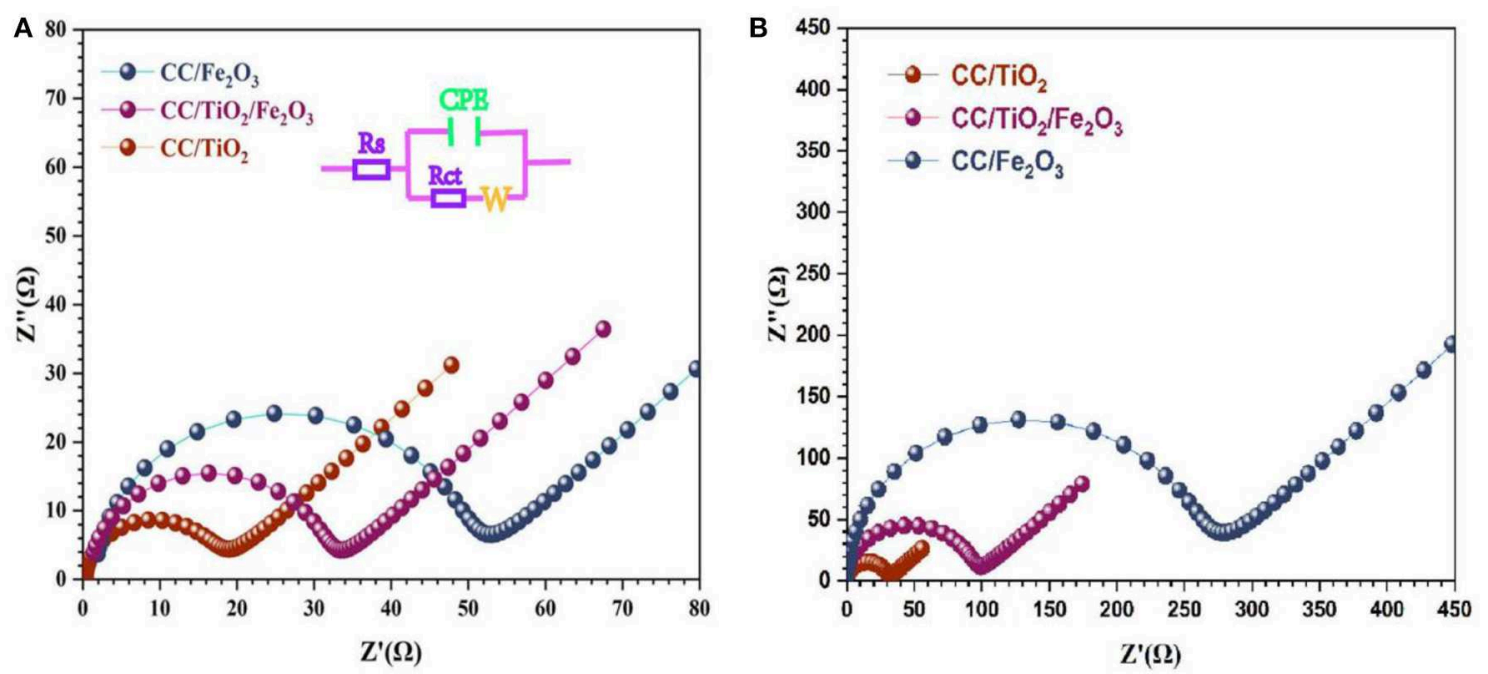

FIGURE 5 | Impedance analysis of $\mathrm{CC} / \mathrm{TiO}_{2} / \mathrm{Fe}_{2} \mathrm{O}_{3}, \mathrm{~s} \mathrm{CC} / \mathrm{TiO}$, and $\mathrm{CC} / \mathrm{Fe}_{2} \mathrm{O}_{3}$ specimens for (A) fresh cell and (B) 50th cycled cell.

high cyclic capacity retention of the nanotube arrays. Even after 200 cycles, the discharge capacity of the $\mathrm{CC} / \mathrm{TiO}_{2} / \mathrm{Fe}_{2} \mathrm{O}_{3}$ nanotube arrays was maintained at approximately $896 \mathrm{mAh}$ $\mathrm{g}^{-1}$, which is much higher than that of the bare $\mathrm{CC} / \mathrm{TiO}_{2}$ nanotube arrays and $\mathrm{CC} / \mathrm{Fe}_{2} \mathrm{O}_{3}$ composites. At the 200th cycle, the Coulombic efficiency of the nanotube array electrodes was approximately $98.7 \%$. Figure 4D displays the rate performance of the tested electrodes in the rate range of $100-1,600 \mathrm{~mA} \mathrm{~g}^{-1}$. The $\mathrm{CC} / \mathrm{TiO}_{2} / \mathrm{Fe}_{2} \mathrm{O}_{3}$ nanotube array electrode maintained a discharge capacity of approximately $742 \mathrm{mAh} \mathrm{g}^{-1}$ even when the discharge rate was increased to $1,600 \mathrm{~mA} \mathrm{~g}^{-1}$. Meanwhile, the discharge capacity of the $\mathrm{CC} / \mathrm{Fe}_{2} \mathrm{O}_{3}$ composite electrode was only approximately $397.5 \mathrm{~mA} \mathrm{~g}^{-1}$ at $1,600 \mathrm{~mA} \mathrm{~g}^{-1}$. Compared the previous literature (Luo et al., 2012, 2013; Xia et al., 2014), these charantia-like nanotube arrays exhibit superior capacity and cyclability due to their unique double hollow structure (Table 1).

Figures 4E,F illustrate the SEM images of the $\mathrm{CC} / \mathrm{TiO}_{2} / \mathrm{Fe}_{2} \mathrm{O}_{3}$ nanotube array and the $\mathrm{CC} / \mathrm{Fe}_{2} \mathrm{O}_{3}$ composite electrodes after 200 cycles. The former maintained an integral framework and was tightly adsorbed to the surface of the CC substrate after 200 cycles. Under the same condition, the volume of $\mathrm{Fe}_{2} \mathrm{O}_{3}$ itself changed unprecedentedly upon cycling, resulting in a large alternate stress. As a result, the $\mathrm{CC} / \mathrm{Fe}_{2} \mathrm{O}_{3}$ composite severely fragmented and extensively separated from the CC substrate. Consistent with the charge-discharge test results, the electrical contact loss significantly reduced the cycling life of the $\mathrm{CC} / \mathrm{Fe}_{2} \mathrm{O}_{3}$ composite electrode.

To gain further insight into the electrochemical performance of the test specimens, EIS measurements were carried out at room temperature. Figures 5A,B show the Nyquist plots of the test specimens at their open-circuit voltage. All the test specimens exhibited semi-circular Nyquist plots in the highfrequency region and a straight line in the low-frequency region.
The diameter of the semicircle represents the charge-transfer resistance $\left(R_{\mathrm{CT}}\right)$, while the slope of the line corresponds to the mass transfer of lithium ions $(W)$ (Shen et al., 2019; Zhang et al., 2019). By adding the Ohmic resistance $\left(R_{\mathrm{s}}\right)$ and double-layer capacitance (CPE), the electrochemical system can be fitted to the Randles circuit shown in Figure 5A. As shown in Figure 5, the diameters of the semicircle of the 3D hierarchical charantia-like $\mathrm{CC} / \mathrm{TiO}_{2} / \mathrm{Fe}_{2} \mathrm{O}_{3}$ nanotube arrays and bare $\mathrm{CC} / \mathrm{TiO}_{2}$ nano-arrays are smaller than that of the $\mathrm{CC} / \mathrm{Fe}_{2} \mathrm{O}_{3}$ composite, indicating that the conductivity of the hollow $\mathrm{CC} / \mathrm{TiO}_{2} / \mathrm{Fe}_{2} \mathrm{O}_{3}$ nano-arrays can be effectively improved by their $\mathrm{TiO}_{2}$ nanotube cores. After 200 cycles, the charge-transfer resistance of the $\mathrm{CC} / \mathrm{TiO}_{2} / \mathrm{Fe}_{2} \mathrm{O}_{3}$ nanotube arrays and bare $\mathrm{CC} / \mathrm{TiO}_{2}$ nanotube arrays increased marginally, while that of the $\mathrm{CC} / \mathrm{Fe}_{2} \mathrm{O}_{3}$ composites increased significantly.

\section{CONCLUSIONS}

3D hierarchical charantia-like $\mathrm{TiO}_{2} / \mathrm{Fe}_{2} \mathrm{O}_{3}$ nanotube arrays were fabricated on CC by a simple, two-step, seed-free hydrothermal method. The well-wrapped mesoporous $\mathrm{Fe}_{2} \mathrm{O}_{3}$ nanospheres on $\mathrm{TiO}_{2}$ nanotubes endowed the final nanotube arrays with a larger specific surface area. The hollow framework and its direct contact with the CC current collector led to the good conductivity of the electrode. The low volume expansion of the hollow $\mathrm{TiO}_{2}$ cores combined with the strong adhesion between the two types of metal oxides stabilized the structure of the final nanotube arrays during cycling. The electrochemical results revealed that the charantia-like $\mathrm{TiO}_{2} / \mathrm{Fe}_{2} \mathrm{O}_{3}$ nanotube arrays have high reversible capacity, improved cycling stability, and excellent rate capability. After 200 cycles at a current density of $200 \mathrm{~mA} \mathrm{~g}^{-1}$, the capacity of the nanotube arrays remained at $875 \mathrm{mAh} \mathrm{g}^{-1}$. A rate capability of $\sim 742 \mathrm{mAh} \mathrm{g}^{-1}$ was achieved even when the discharge rate was increased to $1,600 \mathrm{~mA} \mathrm{~g}^{-1}$. 


\section{DATA AVAILABILITY STATEMENT}

The datasets generated for this study are available on request to the corresponding author.

\section{AUTHOR CONTRIBUTIONS}

PX, HZ, AS, and YZha conducted the synthesis. PX, YZha, and YW carried out the characterization and the electrochemical measurements. PX and ZZ co-wrote the manuscript. All authors discussed the data and commented on the manuscript.

\section{REFERENCES}

Deng, S., Zhang,Y., Xie, D., Yang, L., Wang, G., Zheng, X. S., et al. (2019). Oxygen vacancy modulated $\mathrm{Ti}_{2} \mathrm{Nb}_{10} \mathrm{O}_{29-\mathrm{x}}$ embedded onto porous bacterial cellulose carbon for highly efficient lithium ion storage. Nano Energy 58, 355-364. doi: 10.1016/j.nanoen.2019.01.051

Gao, G., Yu, L., Wu, H. B., and Lou, X. W. (2014). Hierarchical tubular structures constructed by carbon-coated $\alpha-\mathrm{Fe}_{2} \mathrm{O}_{3}$ nanorods for highly reversible lithium storage. Small 10, 1741-1745. doi: 10.1002/smll.201303818

Han, H., Song, T., Bae, Y. J., Nazar, L. F., Kim, H., and Paik, U. (2011). Nitridated $\mathrm{TiO}_{2}$ hollow nanofibers as an anode material for high power lithium ion batteries. Energy Environ. Sci. 4, 4532-4536. doi: 10.1039/clee0 $2333 \mathrm{k}$

$\mathrm{He}$, J., Chen, Y., and Manthiram, A. (2018). Vertical $\mathrm{Co}_{9} \mathrm{~S}_{8}$ hollow nanowall arrays grown on a Celgard separator as a multifunctional polysulfide barrier for high-performance Li-S batteries. Energy Environ. Sci. 67611, 2560-2568. doi: 10.1039/C8EE0 0893K

Jiang, T., Bu, F., Feng, X., Shakir, I., Hao, G., and Xu, Y. (2017). Porous $\mathrm{Fe}_{2} \mathrm{O}_{3}$ nanoframeworks encapsulated within three-dimensional graphene as highperformance flexible anode for lithium-ion battery. ACS Nano 11, 5140-5147. doi: 10.1021/acsnano.7b02198

Joshi, B. N., An, S., Jo, H. S., Song, K. Y., Park, H. G., Hwang, S., et al. (2016). Flexible, freestanding, and binder-free $\mathrm{SnOx}-\mathrm{ZnO} /$ carbon nanofiber composites for lithium ion battery anodes. ACS Appl. Mater. Interfaces 814, 9446-9453. doi: 10.1021/acsami.6b01093

Larcher, D., Bonnin, D., Cortes, R., Rivals, I., Personnaz, L., and Tarascon, J. M. (2003). Combined XRD, EXAFS, and mossbauer studies of the reduction by lithium of alpha- $\mathrm{Fe}_{2} \mathrm{O}_{3}$ with various particle size. J. Electrochem. Soc. 150, A1643-A1650. doi: 10.1149/1.1622959

Lee, G., Kim, S., Kim, S., and Choi, J. (2017). $\mathrm{SiO}_{2} / \mathrm{TiO}_{2}$ composite film for high capacity and excellent cycling stability in lithium-ion battery anodes. Adv. Funct. Mater. 27:1703538. doi: 10.1002/adfm.201703538

Li, Y. Y., Cai, Q. F., Wang, L., Li, Q. W., Peng, X., Gao, B., et al. (2016). Mesoporous $\mathrm{TiO}_{2}$ nanocrystals/graphene as an efficient sulfur host material for high-performance lithium-sulfur batteries. ACS Appl. Mater. Interfaces 8, 23784-23792. doi: 10.1021/acsami.6b09479

Liu, B., Zhang, Y., Pan, G., Ai, C., Deng, S., Liu, S., et al. (2019). Ordered lithiophilic sites to regulate Li plating/stripping behavior for superior lithium metal anodes. J. Mater. Chem. A 7, 21794-21801. doi: 10.1039/C9TA09502K

Luo, J. S., Xia, X. H., Luo, Y. S., Guan, C., Liu, J. L., Qi, X. Y., et al. (2013). Rationally designed hierarchical $\mathrm{TiO}_{2} @ \mathrm{Fe}_{2} \mathrm{O}_{3}$ hollow nanostructures for improved lithium ion storage. Adv. Energy Mater. 3, 737-743. doi: 10.1002/aenm.201200953

Luo, Y., Luo, J., Jiang, J., and Zhou, W. (2012). Seed-assisted synthesis of highly ordered $\mathrm{TiO}_{2} @ \alpha-\mathrm{Fe}_{2} \mathrm{O}_{3}$ core/shell arrays on carbon textiles for lithium-ion battery applications. Energy Environ. Sci. 5, 6559-6566. doi: $10.1039 / \mathrm{c} 2 \mathrm{ee} 03396 \mathrm{~h}$

Moretti, A., Kim, G. T., Bresser, D., Renger, K., Paillard, E., Marassi, R., et al. (2013). Investigation of different binding agents for nanocrystalline anatase $\mathrm{TiO}_{2}$ anodes and its application in a novel, green lithium-ion battery. J. Power Sources 221, 419-426. doi: 10.1016/j.jpowsour.2012.07.142

\section{FUNDING}

This work was supported by National Natural Science Foundation of China (grant no. 71401106), Natural Science Foundation of Shanghai (grant no. 14ZR1418700), and Shanghai University of Engineering Science Innovation Fund (grant no. 18KY0504).

\section{ACKNOWLEDGMENTS}

The authors would like to thank Minjie Yan for his help with SEM/EDX analysis.

Partheeban, T., and Sasidharan, M. (2019). Template-free synthesis of $\mathrm{LiV}_{3} \mathrm{O}_{8}$ hollow microspheres as positive electrode for Li-ion batteries. J. Mater Sci. 55, 2155-2165. doi: 10.1007/s10853-019-04086-3

Qi, X., Zhang, H., Zhang, Z., Bian, Y., Shen, A., Xu, P., et al. (2018). Subunits controlled synthesis of three-dimensional hierarchical flowerlike $\alpha-\mathrm{Fe}_{2} \mathrm{O}_{3}$ hollow spheres as high-performance anodes for lithium ion batteries. Appl. Surf. Sci. 452, 174-180. doi: 10.1016/j.apsusc.2018. 04.253

Shen, S., Guo, W., Xie, D., Wang, Y., Deng, S., Zhong, Y., et al. (2018). A synergistic vertical graphene skeleton and $\mathrm{S}-\mathrm{C}$ shell to construct high-performance $\mathrm{TiNb}_{2} \mathrm{O}_{7}$-based core/shell arrays. J. Mater. Chem. A 6, 20195-20204. doi: $10.1039 / \mathrm{C} 8 \mathrm{TA} 06858 \mathrm{E}$

Shen, S., Xia, X., Zhong, Y., Deng, S., Xie, D., Liu, B., et al. (2019). Implanting niobium carbide into trichoderma spore carbon: a new advanced host for sulfur cathodes. Adv. Mater. 31:1900009. doi: 10.1002/adma.2019 00009

Smith, K. A., Savva, A. I., Mao, K. S., Wang, Y., Tenne, D. A., Chen, D., et al. (2019). Effect of proton irradiation on anatase $\mathrm{TiO}_{2}$ nanotube anodes for lithium-ion batteries. J Mater Sci. 54, 13221-13235. doi: 10.1007/s10853-01903825-w

Wang, C., Wu, L., Wang, H., Zuo, W., Li, Y., and Liu, J. (2015). Fabrication and shell optimization of synergistic $\mathrm{TiO}_{2}-\mathrm{MoO}_{3}$ core-shell nanowire array anode for high energy and power density lithium-ion batteries. Adv. Funct. Mater. 25, 3524-3533. doi: 10.1002/adfm.201500634

Wang, X., Fan, L., Gong, D., Zhu, J., Zhang, Q., and Lu, B. (2016). Core-shell Ge@Graphene@ $\mathrm{TiO}_{2}$ nanofibers as a high-capacity and cycle-stable anode for lithium and sodium Ion battery. Adv. Funct. Mater. 26, 1104-1111. doi: 10.1002/adfm.201504589

Wang, Z., Luan, D., Madhavi, S., Hu, Y., and Lou, X. (2012). Assembling carboncoated $\alpha-\mathrm{Fe}_{2} \mathrm{O}_{3}$ hollow nanohorns on the CNT backbone for superior lithium storage capability. Energy Environ. Sci. 5, 5252-5256. doi: 10.1039/C1EE02831F

Xia, H., Xiong, W., Lim, C. K., Yao, Q. F., Wang, Y. D., and Xie, J. P. (2014). hierarchical $\mathrm{TiO}_{2}-\mathrm{B}$ nanowire@ $\alpha-\mathrm{Fe}_{2} \mathrm{O}_{3}$ nanothorn core-branch arrays as superior electrodes for lithium ion microbatteries. Nano Res. 7, 1797-1808. doi: 10.1007/s12274-014-0539-3

Yang, J., Wu, Q., Yang, X., He, S., Khan, J., Meng, Y., et al. (2017). Chestnut-like $\mathrm{TiO}_{2} @ \alpha-\mathrm{Fe}_{2} \mathrm{O}_{3}$ core-shell nanostructures with abundant interfaces for efficient and ultralong life lithium-ion storage. ACS Appl. Mater. Inter. 9, 354-361. doi: $10.1021 /$ acsami.6b12150

Yang, Y., Wang, S., Lin, S., Li, Y., Zhang, W., Chao, Y., et al. (2018). Rational design of hierarchical $\mathrm{TiO}_{2}$ /epitaxially aligned $\mathrm{MoS}_{2}$-carbon coupled interface nanosheets core/shell architecture for ultrastable sodium-ion and lithium-sulfur batteries. Small Methods 2:1800119. doi: 10.1002/smtd.2018 00119

Ying, W., Yu, J., Shi, J., Gu, L., and Yu, Y. (2017). Multichannel porous $\mathrm{TiO}_{2}$ hollow nanofibers with rich oxygen vacancies and high grain boundary density enabling superior sodium storage performance. Small 13:1700129. doi: 10.1002/smll.201700129

Zhang, Z., Xu, P., Zhang, H., Shen, A., and Zhao, Y. (2019). Flexible three-dimensional titanium-dioxide-based hollow nanoflower arrays for advanced lithium-ion battery anodes. ACS Appl. Energy Mater. 2, 5744-5752. doi: 10.1021 /acsaem.9b00869 
Zhao, Q., Liu, J., Li, X., Xia, Z., Zhang, Q., Zhou, M., et al. (2019). Graphene oxide-induced synthesis of button-shaped amorphous $\mathrm{Fe}_{2} \mathrm{O}_{3} / \mathrm{rGO} / \mathrm{CNF}$ films as flexible anode for high-performance lithium-ion batteries. Chem. Eng. J. 369, 215-222. doi: 10.1016/j.cej.2019.03.076

Zhao, Y., Li, X., Yan, B., Xiong, D., Li, D., Lawes, S., et al. (2016), Recent developments and understanding of novel mixed transition-metal oxides as anodes in lithium ion batteries. Adv. Energy Mater. 6:1502175. doi: 10.1002/aenm.201502175

Zhu, C., Xia, X., Liu, J., and Fan, Z., (2014). $\mathrm{TiO}_{2}$ nanotube@SnO $\mathrm{Sn}_{2}$ nanoflake core-branch arrays for lithium-ion battery anode. Nano Energy 4, 105-112. doi: 10.1016/j.nanoen.2013.12.018
Conflict of Interest: The authors declare that the research was conducted in the absence of any commercial or financial relationships that could be construed as a potential conflict of interest.

Copyright (c) $2020 \mathrm{Xu}$, Zhang, Zhang, Shen, Zhao, Zhou and Weng. This is an open-access article distributed under the terms of the Creative Commons Attribution License (CC BY). The use, distribution or reproduction in other forums is permitted, provided the original author(s) and the copyright owner(s) are credited and that the original publication in this journal is cited, in accordance with accepted academic practice. No use, distribution or reproduction is permitted which does not comply with these terms. 